\title{
KIR2DS3 wt Allele
}

National Cancer Institute

\section{Source}

National Cancer Institute. KIR2DS3 wt Allele. NCI Thesaurus. Code C132076.

Human KIR2DS3 wild-type allele is located in the vicinity of 19q13.4 and is approximately $14 \mathrm{~kb}$ in length. This allele, which encodes killer cell immunog lobulin-like receptor 2DS3 protein, plays a role in HLA-C binding and immunity. 